\title{
Variants in SARS-CoV-2 Associated with Mild or Severe Outcome
}

\author{
Jameson D. Voss, MD, MPH, FACPM, FISO ${ }^{1}$ \\ Martin Skarzynski, PhD $^{2}$ \\ Erin M. McAuley, PhD $^{2}$ \\ Ezekiel J. Maier, PhD $^{2}$ \\ Thomas Gibbons, $\mathbf{P h D}^{3}$ \\ Anthony C. Fries, $\mathbf{P h D}^{4}$ \\ Richard R. Chapleau, PhD, MMOAS ${ }^{4}$
}

\author{
${ }^{1}$ US Air Force Medical Readiness Agency, Falls Church, VA 22042 \\ ${ }^{2}$ Booz Allen Hamilton, Bethesda, MD 20814 \\ ${ }^{3} 59^{\text {th }}$ Medical Wing, Joint Base San Antonio, TX 78234 \\ ${ }^{4}$ US Air Force School of Aerospace Medicine, Wright Patterson AFB, OH 45433
}

Word count: Abstract - 224 words; Body - 2920 words; 2 Figures Address correspondence and reprint requests to:

Jameson D. Voss, MD, MPH

7700 Arlington Blvd, Falls Church, VA, 22042

Phone: (719) 232-3509; E-mail: jameson.d.voss.mil@mail.mil

Conflict of interest statement: JDV, MS, EMM, EJM, TG, ACF, and RRC have no conflict of interest disclosures.

Disclaimer: The views expressed in this article are those of the authors and do not necessarily reflect the official policy or position of the Air Force, the Department of Defense, or the U.S. Government. Clearance PAIRS CASE \#2020-0613.

Acknowledgements: The authors gratefully acknowledge the contributors, originating and submitting laboratories of the sequences from the GISAID EpiCoV Database (Elbe and Buckland-Merrett, 2017; Shu and McCauley, 2017), the basis of this research. A detailed list of contributing labs to GISAID is available in the Supplementary Information. 
medRxiv preprint doi: https://doi.org/10.1101/2020.12.01.20242149; this version posted December 3, 2020. The copyright holder for this preprint (which was not certified by peer review) is the author/funder, who has granted medRxiv a license to display the preprint in perpetuity.

This article is a US Government work. It is not subject to copyright under 17 USC 105 and is also made available for use under a CCO license.

\section{Abstract:}

48 Introduction: The coronavirus disease 2019 (COVID-19) pandemic is a global public health 49 emergency causing a disparate burden of death and disability around the world. The molecular

50 characteristics of the virus that predict better or worse outcome are largely still being discovered.

51 Methods: We downloaded 155,958 severe acute respiratory syndrome coronavirus 2 (SARS-

52 CoV-2) genomes from GISAID and evaluated whether variants improved prediction of reported

53 severity beyond age and region. We also evaluated specific variants to determine the magnitude

54 of association with severity and the frequency of these variants among the genomes.

55 Results: Logistic regression models that included viral genomic variants outperformed other models (AUC=0.91 as compared with 0.68 for age and gender alone; $\mathrm{p}<0.001)$. Among

57 individual variants, we found 17 single nucleotide variants in SARS-CoV-2 have more than two-

58 fold greater odds of being associated with higher severity and 67 variants associated with $\leq 0.5$

59 times the odds of severity. The median frequency of associated variants was $0.15 \%$ (interquartile 60 range $0.09 \%-0.45 \%$ ). Altogether $85 \%$ of genomes had at least one variant associated with patient 61 outcome.

62 Conclusion: Numerous SARS-CoV-2 variants have two-fold or greater association with odds of

63 mild or severe outcome and collectively, these variants are common. In addition to

64 comprehensive mitigation efforts, public health measures should be prioritized to control the

65 more severe manifestations of COVID-19 and the transmission chains linked to these severe

66 cases. 
medRxiv preprint doi: https://doi.org/10.1101/2020.12.01.20242149; this version posted December 3, 2020. The copyright holder for this preprint (which was not certified by peer review) is the author/funder, who has granted medRxiv a license to display the preprint in perpetuity.

This article is a US Government work. It is not subject to copyright under 17 USC 105 and is also made available for use under a CCO license.

\section{Introduction}

Since the coronavirus disease 2019 (COVID-19) pandemic emerged, humans have faced unprecedented disruption from the newfound obligate parasite. Within the United States alone, the unwelcome guest has already caused an estimated 2.5 million years of life lost.(1) Beyond the United States, the global burden is substantial and growing, but it is not uniform; continents, nations, communities, families, and patients are all affected differently. Understanding the basis for this variability is an important global health priority.

One of the most common measures to describe the severity of COVID-19 is the infection fatality ratio (IFR) or the number of deaths for every infection. There are widespread differences in IFR between studies, $(2-4)$ and this heterogeneity is not due to chance alone $(\mathrm{p}<0.001)$.(2) One metaanalysis of 26 studies estimated an IFR of $0.68 \%(0.53-0.82 \%)$ while cautioning this was likely an "underestimate" and another meta-analysis with 61 studies estimated a median IFR of $0.26 \%$, outside the range of the first meta-analysis. $(2,3)$

Other studies have suggested the variability in infection fatality ratio is more consistent when infections are stratified by age, but is more likely to vary between studies when considering the population above age 65.(4-6) In fact, one paper even estimated that "differences in age structure of the population and the age-specific prevalence of COVID-19 explain nearly $90 \%$ of the geographical variation in population IFR."(4) Although vulnerable age groups should be protected as recommended by the U.S. Centers for Disease Control and Prevention (CDC), there are likely more factors at play in the IFR than age alone. First, there is variability among some younger groups. In the most recent meta-analysis among those age $<70$, IFR estimates varied from $0.00 \%$ to $0.31 \%$ with a median of $0.05 \%$.(3) 
medRxiv preprint doi: https://doi.org/10.1101/2020.12.01.20242149; this version posted December 3, 2020. The copyright holder for this preprint (which was not certified by peer review) is the author/funder, who has granted medRxiv a license to display the preprint in perpetuity.

This article is a US Government work. It is not subject to copyright under 17 USC 105 and is also made available for use under a CCO license.

90 Second, even within the same hospital systems, there are strong time trends in case fatality rate

91 after adjusting for baseline characteristics/risk (7) even at the national scale (8), which authors

92 attributed to better treatment. Unless baseline risk adjustments were inadequate, there are likely

93 time trends in IFR, which would also help reconcile the disparate estimates noted in the two

94 meta-analyses cited above.

95 Another possibility is severe acute respiratory syndrome coronavirus 2 (SARS-CoV-2) virulence

96 could differ across geographic locations because some local strains have higher or lower

97 virulence than others. Previous reports have argued that evolution of attenuated strains is

98 expected for RNA viruses and that “determination of naturally circulating attenuated SARS-

99 CoV-2 variants is an urgent matter.” (9) Previous publications on evolution of virulence

100 observed that pathogens transmitting with a respiratory route (unlike vector-borne diseases)

101 typically evolve toward lower virulence after emergence because healthier hosts tend to engage 102 in more social contact.(10)

103 Using publicly available data from GISAID (Global Initiative on Sharing Avian Influenza Data), 104 we interrogate the relationship between SARS-CoV-2 variants and associated patient outcomes 105 in the GISAID metadata. We differentiate between severe and mild patient outcomes and utilize 106 a logistic regression model in order to better understand how viral genomic SARS-CoV-2

107 variants are linked with COVID-19 patient outcomes.

109 Methods: 
medRxiv preprint doi: https://doi.org/10.1101/2020.12.01.20242149; this version posted December 3, 2020. The copyright holder for this preprint

(which was not certified by peer review) is the author/funder, who has granted medRxiv a license to display the preprint in perpetuity.

This article is a US Government work. It is not subject to copyright under 17 USC 105 and is also made available for use under a CCO license.

SARS-CoV-2 genome sequences were obtained from GISAID (Global Initiative on Sharing All Influenza Data) on October 21, 2020 (11, 12), (GISAID Acknowledgments Table,

Supplementary Table 1). GISAID sequences were filtered to include those of human origin.

FASTA sequences were aligned to the reference sequence, Wuhan-Hu-1 (NCBI: NC_045512.2;

GISAID: EPI_ISL_402125) using Minimap2 (version 2.17).(13) Resulting VCF (Variant Call

Format) files were annotated using SnpEff (version 5.0) and filtered using SnpSift.(14, 15) The

shell scripts used for variant alignment and variant calling, along with the Python scripts used to perform the steps described below, are available on GitHub at https://github.com/mskar/variants.

\section{Metadata Preprocessing and Cohort Building}

Raw GISAID patient data was parsed from the JSON file using Python (version 3.8.2). Patient outcomes were then aggregated into positive ("Mild") outcomes or negative ("Severe") outcomes (detailed in Supplemental Figure 1). Briefly, "Mild" outcomes included: Outpatient, Asymptomatic, Mild, Home/Isolated/Quarantined, and Not Hospitalized. "Severe" outcomes included: Hospitalized (including severe, moderate, and stable) and Deceased (Death). Patient outcomes that were unclear or empty were not included in our analyses.

\section{Variant and Metadata Modeling}

Annotated VCF files were parsed, pivoted to wide format, and joined with GISAID patient data using Pandas (version 1.0.3).(16) Logistic regression models with the default L1 penalty (Lasso regularization) were fit to the patient (rows) and variant (columns) data using Scikit-learn (version 0.23.2).(17) Logistic regression model Area Under the Curve (AUC) and accuracy 
medRxiv preprint doi: https://doi.org/10.1101/2020.12.01.20242149; this version posted December 3, 2020. The copyright holder for this preprint

(which was not certified by peer review) is the author/funder, who has granted medRxiv a license to display the preprint in perpetuity.

This article is a US Government work. It is not subject to copyright under 17 USC 105 and is also made available for use under a CCO license.

133 values were calculated using Scikit-learn.(17) Models were persisted as pickle files using joblib

134 (version 0.14 .1 ).

Plotting and Statistical Analysis

137 Scatter and bar plots were created using Pandas (version 1.0.3),(16) Matplotlib (version 3.2.1),(18) and Seaborn (version 0.10.1).(19) Logistic regression model AUC p-values and Chisquare test p-values for association of variants with "Severe" outcomes were obtained using Scipy (version 1.5.0).(20) Variant frequency was calculated using Pandas.(16) Genome position tracks were added to scatterplots using DNA Features Viewer (version 3.0.3).(21) ROC curves were plotted using Scikit-learn (version 0.23.2),(17) and Matplotlib.(18) Logistic regression model Area Under the Curve (AUC) and accuracy values were calculated using Scikit-learn.(17)

Results:

\section{Sample population characteristics}

147 We collected a total of 155,958 viral genomes along with clinical metadata. The metadata

148 included numerous entries whereby the severity of the condition could not readily be discerned.

149 For example, "recovering", "recovered and released", and "mild symptoms inpatient for

150 observation" were found in the raw data and were not included. The full downloaded dataset

151 included 148,121 entries with empty or unknown clinical observations, and 4,200 entries for

152 which clinical severity could not be classified. From the remaining 3,637 sequences with clear

153 severity indications, we generated two classes (Supplemental Figure S1) by recoding the 
medRxiv preprint doi: https://doi.org/10.1101/2020.12.01.20242149; this version posted December 3, 2020. The copyright holder for this preprint

(which was not certified by peer review) is the author/funder, who has granted medRxiv a license to display the preprint in perpetuity.

This article is a US Government work. It is not subject to copyright under 17 USC 105 and is also made available for use under a CCO license.

154

155

156

157

158

159

160

161

162

163

164

165

166

167

168

169

170

171

172

173

174

175

observational metadata into consistent terminology and creating a "Severe" class of "deceased", "hospitalized", "ICU”, and "pneumonia" (n=2,870); and a "Mild" class of "outpatient", "mild", “epidemiology study", "asymptomatic", "screening”, and "stable in quarantine" (n=767). 85\% of these genomes had at least one variant associated with patient outcome. Viral sequences were obtained from the six major geographical regions in GISAID between January and October 2020 (Supplemental Figure S2).

\section{SARS-CoV-2 variants associated with "Severe" / "Mild" outcome categories}

The overwhelming majority of variants in the SARS-CoV-2 genomes assessed were rare, with only 12 common variants with at least a 5\% minor allele frequency (Figure 1C). Two of these common variants (C26735T and C28311T) were associated with "Severe" or "Mild" outcomes, as measured by having an odds ratio of greater than 2 or $\leq 0.5$, respectively. We also observed 84 of 157 rare variant associations with "Severe" or "Mild" outcomes. Collectively, 17 variants were associated with "Severe" classification with at least an odds ratio of 2, while we found 67 associations with "Mild" classification $(\mathrm{OR} \leq 0.5)$. The variants associated with outcomes were distributed across the genome, including the strongest "Severe" association within the C-terminal end of the spike protein (Figure 1B). The majority of variants characterized here were transitions (121, 71\%), with $47 \%$ of those transitions (79) being C>T (Supplemental Figure S3). All individual variant associations and frequencies are reported in Supplementary Table 2.

\section{Predicting clinical outcomes for patients based upon clinical metadata and viral genomics}

Age and gender have been previously reported to be predictive of clinical outcomes.(22) Our observations predicting "Severe" outcomes confirm these prior associations (Figure 2); however 
medRxiv preprint doi: https://doi.org/10.1101/2020.12.01.20242149; this version posted December 3, 2020. The copyright holder for this preprint (which was not certified by peer review) is the author/funder, who has granted medRxiv a license to display the preprint in perpetuity. This article is a US Government work. It is not subject to copyright under 17 USC 105 and is also made available for use under a CCO license.

we found that the c-statistic for predictions based on age or age and gender are only slightly better than random chance at $0.677(0.642-0.712)$ and $0.679(0.644-0.714)$, respectively. We hypothesized that viral genomic variants in the virus could also contribute to severity classification. When accounting for the region of collection, we observed an increased c-statistic to 0.817 (0.817-0.818). Previous observations show that regions tend to be dominated by individual viral clades, and we found that adding clade to an age/gender/region model resulted in moderate improvement of accuracy ( $81 \%$ vs. $86 \%$, respectively) with a nearly identical AUC of $0.818(0.817-0.818)$. While the difference between region and clade appears insignificant, adding clade-level information increased the predictive ability of our model beyond age and gender alone. We then considered whether variant-level information would further improve model performance. We found that substituting clade with 4,499 genomic variants in the model increased the c-statistic to $0.911(0.910-0.911)$, significantly improving predictability for clinical outcomes. In addition to the improvement in c-statistic, we compared the accuracy of our predictions, which started at $81 \%$ for the age-only model and improved to $86 \%$ and $88 \%$ for each additional step in the model building before finally reaching a maximum at $91 \%$ accuracy for the age/gender/region/variant model.

Classifications based solely on age or on age and gender resulted in insignificant odds ratios in our models. Both models had the same odds ratio (4.4), confidence interval (2.8-6.0), and pvalue (0.072). However, the other three models all had significant odds ratios with p-values less than 0.0001. Consistent with the AUC results, the odds ratio was greatest for the full model (age/gender/region/variant) followed by age/gender/region/clade and finally age/gender/region (odds ratios: 12.3 (11.8-12.8), 8.4 (8.0-8.9), and 8.0 (7.6-8.4), respectively). Similarly, the negative likelihood ratio for the full model displayed a large reduction in the likelihood of a 
medRxiv preprint doi: https://doi.org/10.1101/2020.12.01.20242149; this version posted December 3, 2020. The copyright holder for this preprint

(which was not certified by peer review) is the author/funder, who has granted medRxiv a license to display the preprint in perpetuity.

This article is a US Government work. It is not subject to copyright under 17 USC 105 and is also made available for use under a CCO license.

patient classified as "Mild" developing "Severe" symptoms (-LR=0.039) as compared to a moderate reduction in the post-test outcomes for the age-only or age and gender models ($\mathrm{LR}=0.231$ for both models).

\section{Discussion:}

We demonstrate that including genomic viral variants can substantially improve classification of COVID-19 patient outcomes as compared with models using only age and region. Moreover, in our models, we observe that some individual variants are particularly important with substantial associations with severity, and that collectively these variants are not rare.

Associations between viral genomic variants and patient outcomes are not unexpected.

Consistent with known patterns in the evolution of virulence in RNA viruses $(9,10,23)$, we would expect many common strains have differing association with patient severity by this point in the pandemic by chance alone and even as sampling is more likely to occur with severe outcomes, variants correlated with mild outcomes are still being identified.

Though respiratory pathogens often evolve toward lower virulence, there have been historical exceptions.(24) Modeling future fitness landscapes suggests that even partial isolation of symptomatic cases can substantially reduce deaths with less transmission in the short term. Importantly, this isolation can also potentially alter the evolutionary path by favoring less virulent strains.(24) Alterations in virulence can happen with a small number of selections. For example, E. faecalis evolved from a pathogen to a commensal strain in 15 passages in a worm model, but most of the worm phenotype changed after just 5 rounds of bacterial selection.(25) A mouse experiment showed higher virulence after 10 passages of a modified SARS-CoV-2 virus 
medRxiv preprint doi: https://doi.org/10.1101/2020.12.01.20242149; this version posted December 3, 2020. The copyright holder for this preprint (which was not certified by peer review) is the author/funder, who has granted medRxiv a license to display the preprint in perpetuity.

This article is a US Government work. It is not subject to copyright under 17 USC 105 and is also made available for use under a CCO license.

221 with an additional $\sim 1 \%$ drop in mouse body weight with each selection (26). Based upon these

222 findings and the large number of passages in the human outbreak, it can be expected that

223 significant evolution affecting virulence could occur in the SARS-CoV-2 genome.

224 Indeed, others have previously found and characterized individual variants with in vitro assays

225 (27) or provided correlates of severity with any change in protein coding,(28) or genomic

226 correlates of mortality.(29) We have taken a comprehensive approach to describe all variants

227 associated with mild or severe outcome regardless of whether it is synonymous. There are

228 challenges in identifying signatures of selection in non-coding regions, but "for RNA

229 viruses...critical aspects of the life cycle rely on molecular processes that are not reflected in

230 protein sequence."(30) Empiric tests of selection and structural modeling of RNA and protein

231 interaction can identify regions under selection without using the ratio of nonsynonymous to

232 synonymous mutations.(30) Studies of selection in SARS-CoV-2 have also advised not to

233 underestimate the role of synonymous substitutions.(31) Beyond RNA molecule interactions,

234 there also appear to be selective pressures on which codon is used for an amino acid, which

235 could be attributed to tRNA abundance (32) or could be related to broader patterns of host RNA

236 editing involving deamination and similar mechanisms. (33-35) Alternatively, a variant

237 correlated with severity might represent an epiphenomenon that is linked to multiple variants that

238 each have a smaller association with severity. Regardless of the applicability of these

239 explanations for why synonymous changes could be important indicators of virulence, we

240 wanted to take an agnostic approach to characterize all variants correlated with severity so that

241 they could be further resolved with additional study and additional surveillance (particularly

242 among asymptomatic cases). These studies, in addition to comprehensive prognostic study, could

243 better clarify how unexpected a patient's severity was as compared with additional risk factors. 
medRxiv preprint doi: https://doi.org/10.1101/2020.12.01.20242149; this version posted December 3, 2020. The copyright holder for this preprint (which was not certified by peer review) is the author/funder, who has granted medRxiv a license to display the preprint in perpetuity.

This article is a US Government work. It is not subject to copyright under 17 USC 105 and is also made available for use under a CCO license.

244 For example, one mutation we identified (C13620T) is associated with 5.9 times the odds of

245 severe disease. Although it does not result in any change in an amino acid of the NSP12 (RNA-

246 dependent RNA polymerase), it could result in altered expression. Because NSP12 is required

247 for the transcription of all viral RNA in coronaviruses (36), increased replication could increase

248 virulence.

249 Other mutations were nonsynonymous. We identified two previously reported spike mutations, V1176F (G25088T) and S477N (G22992A), as important indicators for COVID-19 disease severity. Recent protein modeling studies have indicated that both mutations cause favorable

252 energetic changes that result in a more flexible Spike protein and can change RBD-ACE2

253 binding. Importantly, both mutations have been associated with higher mortality rates, and are

254 therefore expected to have significant impacts on public health.(37, 38) Other mutations were observed less commonly, but could still be relevant for understanding higher viral pathogenesis.

256 The G26144T causes amino acid change G251V in Orf3a and was associated with 4.3 times the 257 odds of severe disease. Protein trafficking is a complex multifactorial process (39) and Orf3a

258 functions as a modulator of the trafficking properties of the spike protein of SARS-1 and is 259 dependent on the protein-protein interaction of Orf3a and S.(40) A structural analysis of the $260 \mathrm{G} 251 \mathrm{~V}$ in Orf3a of SARS-CoV-2 results in significant changes in the overall protein structure 261 and weaker affinity for both the S and M proteins with Orf3a. One possible outcome of the 262 weaker Orf3a-S and Orf3a-M interaction could be an increased Orf3a-TRAF3 interaction 263 resulting in increased activation of the NLRP3 inflammasome by promoting TRAF3-dependent 264 ubiquitination of ASC. $(41,42)$ Thus, the altered protein-protein interaction of the G251V Orf3a 265 may impact the trafficking of Orf3a resulting in a higher propensity for inflammatory cytokine activation. 
medRxiv preprint doi: https://doi.org/10.1101/2020.12.01.20242149; this version posted December 3, 2020. The copyright holder for this preprint (which was not certified by peer review) is the author/funder, who has granted medRxiv a license to display the preprint in perpetuity. This article is a US Government work. It is not subject to copyright under 17 USC 105 and is also made available for use under a CCO license.

267 We also identified that the C28311T mutation was associated with a lower odds ratio of 0.14.

268 This mutation lies within the probe of the N1 assay in the CDC's PCR assay (43), creating a P13L change in the nucleocapsid protein. A previous study evaluated how this mutation may alter protein-protein interaction and proposed it impacted virus stability, potentially contributing to lower pathogenesis.(44) Additional follow-up studies will help to illuminate effects of these

272 variants on viral fitness, infectivity, host response, and evolutionary trajectory. Identifying genetic variants associated with outcomes could provide mechanistic understanding

274 of the life cycle.(45) Efforts such as the CDC's annual influenza surveillance rely upon understanding those key genetic variants to predict seasonal intensity and attempt to develop 276 effective countermeasures (vaccines) (https://www.cdc.gov/flu/weekly/overview.htm).

277 Although deep molecular insights are important, they are not necessary for public health

278 applications. The CDC offers symptom-based criteria for prioritizing testing and symptom-based 279 criteria are also included in recommendations for prioritizing contact tracing

280 (https://www.cdc.gov/coronavirus/2019-ncov/php/contact-tracing/contact-tracing-plan/contact-

281 tracing.html\#). By prioritizing cases and contacts with symptoms (as compared with

282 asymptomatic cases and their asymptomatic contacts) in addition to the recommended global 283 mitigation efforts, there could be relative selective pressure against strains that are more likely to 284 cause symptoms. This could favor the emergence of attenuated strains over the long term.

285 The COVID-19 pandemic demonstrated the limitations of the global healthcare system in 286 intensive care units, mechanical ventilators, and emerging therapeutics and other medical 287 countermeasures. $(46,47)$ Early in the outbreak, cities such as New York became inundated with 288 infections and their ability to adequately sort and treat patients was quickly overwhelmed.(48)

289 The existence of a rapid and accurate tool that could help identify COVID-19 patients or clusters 
medRxiv preprint doi: https://doi.org/10.1101/2020.12.01.20242149; this version posted December 3, 2020. The copyright holder for this preprint (which was not certified by peer review) is the author/funder, who has granted medRxiv a license to display the preprint in perpetuity. This article is a US Government work. It is not subject to copyright under 17 USC 105 and is also made available for use under a CCO license.

290

291

292

293

294

295

296

297

298

299

300

301

302

303

304

305

306

307

308

309

310

311

that are more likely to experience severe symptoms or require intensive medical resources (e.g., inpatient hospitalization and ventilation) may be able to help healthcare systems allocate resources to the regions with the most critical needs. Therefore, by providing a molecular risk factor for more severe outcomes, these findings could help prioritize limited treatment supplies to those at greatest risk, particularly as therapeutic interventions for infectious disease often need to be given early in the disease course (e.g., empiric antivirals for influenza).

There are limitations with our analyses. First, the SARS-CoV-2 genomes uploaded to GISAID are not necessarily representative of all circulating genomes, which can introduce a selection or sampling bias into our analyses based on region, patient severity, or other unmeasured factors. In Supplemental Figure S2 we show the sampling patterns over time by our patient severity categorization. We sought to mitigate these limitations by eliminating the categories that had ambiguous severity (e.g., "live" or "recovered"), and adjusting the associations for known confounders. In addition, we do not seek to make causal claims about any specific viral genomic variant. In aggregate these variants are predictive of outcome and the candidates we identify can be further studied using molecular and other methods.

In summary, we have demonstrated that some SARS-CoV-2 genomic variants are strong predictors of COVID-19 disease severity, and these variants appear to be commonly circulating.

This study provides a rationale for prioritizing control efforts for cases and populations manifesting with unusually high severity, consistent with symptom-based criteria for testing used by the CDC. Longitudinal monitoring of genomic variants within a novel pathogen such as

SARS-CoV-2 will be important for understanding drivers and effects of its evolution and ultimately, its spread or control. 
medRxiv preprint doi: https://doi.org/10.1101/2020.12.01.20242149; this version posted December 3, 2020. The copyright holder for this preprint (which was not certified by peer review) is the author/funder, who has granted medRxiv a license to display the preprint in perpetuity. This article is a US Government work. It is not subject to copyright under 17 USC 105 and is also made available for use under a CCO license.

\section{References}

1. Elledge SJ. 2.5 Million Person-Years of Life Have Been Lost Due to COVID-19 in the United States. medRxiv. 2020.

2. Meyerowitz-Katz G, Merone L. A systematic review and meta-analysis of published research data on COVID-19 infection-fatality rates. medRxiv. 2020.

3. Ioannidis JP. The infection fatality rate of COVID-19 inferred from seroprevalence data. Bulletin of the World Health Organization. 2020. Epub 14 Oct 2020.

4. Levin AT, Hanage WP, Owusu-Boaitey N, Cochran KB, Walsh SP, Meyerowitz-Katz G. ASSESSING THE AGE SPECIFICITY OF INFECTION FATALITY RATES FOR COVID-19: SYSTEMATIC REVIEW, METAANALYSIS, AND PUBLIC POLICY IMPLICATIONS. medRxiv. 2020.

5. O'Driscoll M, Dos Santos GR, Wang L, Cummings DA, Azman AS, Paireau J, et al. Age-specific mortality and immunity patterns of SARS-CoV-2 infection in 45 countries. medRxiv. 2020.

6. Onder G, Rezza G, Brusaferro S. Case-fatality rate and characteristics of patients dying in relation to COVID-19 in Italy. Jama. 2020;323(18):1775-6.

7. Horwitz L, Jones SA, Cerfolio RJ, Francois F, Greco J, Rudy B, et al. Trends in Covid-19 riskadjusted mortality rates in a single health system. Journal of Hospital Medicine. 2020. Epub October 23, 2020. doi: 10.12788/jhm.3552.

8. Dennis J, McGovern A, Vollmer S, Mateen BA. Improving COVID-19 critical care mortality over time in England: A national cohort study, March to June 2020. medRxiv. 2020.

9. Armengaud J, Delaunay-Moisan A, Thuret JY, Van Anken E, Acosta-Alvear D, Aragón T, et al. The importance of naturally attenuated Sars-Cov-2 in the fight against Covid-19. Environmental Microbiology. 2020;22(6):1997-2000.

10. Ewald PW. Evolution of virulence. Infectious disease clinics of North America. 2004;18(1):1. 11. Elbe S, Buckland-Merrett G. Data, disease and diplomacy: GISAID's innovative contribution to global health. Global Challenges. 2017;1(1):33-46.

12. Shu Y, McCauley J. GISAID: Global initiative on sharing all influenza data-from vision to reality. Eurosurveillance. 2017;22(13):30494.

13. Li H. Minimap2: pairwise alignment for nucleotide sequences. Bioinformatics. 2018;34(18):3094100.

14. Cingolani P, Platts A, Wang LL, Coon M, Nguyen T, Wang L, et al. A program for annotating and predicting the effects of single nucleotide polymorphisms, SnpEff: SNPs in the genome of Drosophila melanogaster strain w1118; iso-2; iso-3. Fly. 2012;6(2):80-92.

15. Cingolani P, Patel VM, Coon M, Nguyen T, Land SJ, Ruden DM, et al. Using Drosophila melanogaster as a Model for Genotoxic Chemical Mutational Studies with a New Program, SnpSift. Frontiers in Genetics. 2012;3.

16. McKinney W, editor Data structures for statistical computing in python. Proceedings of the 9th Python in Science Conference; 2010: Austin, TX.

17. Pedregosa F, Varoquaux G, Gramfort A, Michel V, Thirion B, Grisel O, et al. Scikit-learn: Machine learning in Python. the Journal of machine Learning research. 2011;12:2825-30.

18. Hunter JD. Matplotlib: A 2D graphics environment. Computing in science \& engineering. 2007;9(3):90-5.

19. Waskom M, Botvinnik O, Gelbart M, Ostblom J, Hobson P, Lukauskas S. mwaskom/seaborn: v0. 11.0 (Sepetmber 2020); 2020. DOI; 2020.

20. Virtanen $P$, Gommers R, Oliphant TE, Haberland M, Reddy $T$, Cournapeau D, et al. SciPy 1.0: fundamental algorithms for scientific computing in Python. Nature methods. 2020;17(3):261-72.

21. Zulkower V, Rosser S. DNA Features Viewer, a sequence annotations formatting and plotting library for Python. bioRxiv. 2020. 
medRxiv preprint doi: https://doi.org/10.1101/2020.12.01.20242149; this version posted December 3, 2020. The copyright holder for this preprint (which was not certified by peer review) is the author/funder, who has granted medRxiv a license to display the preprint in perpetuity. This article is a US Government work. It is not subject to copyright under 17 USC 105 and is also made available for use under a CCO license.

22. Matsushita K, Ding N, Kou M, Hu X, Chen M, Gao Y, et al. The relationship of COVID-19 severity with cardiovascular disease and its traditional risk factors: A systematic review and meta-analysis. Global heart. 2020;15(1).

23. Holmes EC. The evolution and emergence of RNA viruses: Oxford University Press; 2009.

24. Rochman ND, Wolf YI, Koonin EV. Evolution of Human Respiratory Virus Epidemics. medRxiv. 2020:2020.11.23.20237503. doi: 10.1101/2020.11.23.20237503.

25. King KC, Brockhurst MA, Vasieva O, Paterson S, Betts A, Ford SA, et al. Rapid evolution of microbe-mediated protection against pathogens in a worm host. The ISME journal. 2016;10(8):1915-24. 26. Leist SR, Dinnon III KH, Schäfer A, Longping VT, Okuda K, Hou YJ, et al. A Mouse-Adapted SARSCoV-2 Induces Acute Lung Injury and Mortality in Standard Laboratory Mice. Cell. 2020.

27. Yao H-P, Lu X, Chen Q, Xu K, Chen Y, Cheng L, et al. Patient-derived mutations impact pathogenicity of SARS-CoV-2. CELL-D-20-01124. 2020.

28. Nagy A, Pongor S, Gyorffy B. Different mutations in SARS-CoV-2 associate with severe and mild outcome. medRxiv. 2020.

29. Hahn G, Wu CM, Lee S, Hecker J, Lutz SM, Haneuse S, et al. Mutations in SARS-CoV-2 spike protein and RNA polymerase complex are associated with COVID-19 mortality risk. bioRxiv. 2020.

30. Berrio A, Gartner V, Wray GA. Positive selection within the genomes of SARS-CoV-2 and other Coronaviruses independent of impact on protein function. PeerJ. 2020;8:e10234.

31. Velazquez-Salinas L, Zarate S, Eberl S, Gladue DP, Novella I, Borca MV. Positive Selection of ORF1ab, ORF3a, and ORF8 Genes Drives the Early Evolutionary Trends of SARS-CoV-2 During the 2020 COVID-19 Pandemic. Frontiers in Microbiology. 2020;11:2592.

32. Dilucca M, Forcelloni S, Georgakilas AG, Giansanti A, Pavlopoulou A. Codon Usage and Phenotypic Divergences of SARS-CoV-2 Genes. Viruses. 2020;12(5):498.

33. Simmonds P. Rampant $\mathrm{C} \rightarrow U$ hypermutation in the genomes of SARS-CoV-2 and other coronaviruses: Causes and consequences for their short-and long-term evolutionary trajectories. MSphere. 2020;5(3).

34. Matyášek R, Kovařík A. Mutation patterns of human SARS-CoV-2 and Bat RaTG13 coronavirus genomes are strongly biased towards $\mathrm{C}>\mathrm{U}$ transitions, indicating rapid evolution in their hosts. Genes. 2020;11(7):761.

35. Di Giorgio S, Martignano F, Torcia MG, Mattiuz G, Conticello SG. Evidence for host-dependent RNA editing in the transcriptome of SARS-CoV-2. Science Advances. 2020:eabb5813.

36. Subissi L, Posthuma CC, Collet A, Zevenhoven-Dobbe JC, Gorbalenya AE, Decroly E, et al. One severe acute respiratory syndrome coronavirus protein complex integrates processive RNA polymerase and exonuclease activities. Proceedings of the National Academy of Sciences. 2014;111(37):E3900-E9. 37. Farkas C, Mella A, Haigh JJ. Large-scale population analysis of SARS-CoV2 whole genome sequences reveals host-mediated viral evolution with emergence of mutations in the viral Spike protein associated with elevated mortality rates. medRxiv. 2020.

38. Turoňová B, Sikora M, Schürmann C, Hagen WJ, Welsch S, Blanc FE, et al. In situ structural analysis of SARS-CoV-2 spike reveals flexibility mediated by three hinges. Science. 2020;370(6513):2038.

39. Gibbons TF, Storey SM, Williams CV, McIntosh A, Mitchel DM, Parr RD, et al. Rotavirus NSP4: Cell type-dependent transport kinetics to the exofacial plasma membrane and release from intact infected cells. Virology journal. 2011;8(1):1-20.

40. Tan Y-J. The Severe Acute Respiratory Syndrome (SARS)-coronavirus 3a protein may function as a modulator of the trafficking properties of the spike protein. Virology journal. 2005;2(1):1-5.

41. Siu KL, Yuen KS, Castano-Rodriguez C, Ye ZW, Yeung ML, Fung SY, et al. Severe acute respiratory syndrome Coronavirus ORF3a protein activates the NLRP3 inflammasome by promoting TRAF3dependent ubiquitination of ASC. The FASEB Journal. 2019;33(8):8865-77. 
medRxiv preprint doi: https://doi.org/10.1101/2020.12.01.20242149; this version posted December 3, 2020. The copyright holder for this preprint (which was not certified by peer review) is the author/funder, who has granted medRxiv a license to display the preprint in perpetuity.

This article is a US Government work. It is not subject to copyright under 17 USC 105 and is also made available for use under a CCO license.

408 42. Issa E, Merhi G, Panossian B, Salloum T, Tokajian S. SARS-CoV-2 and ORF3a: Nonsynonymous 409 Mutations, Functional Domains, and Viral Pathogenesis. Msystems. 2020;5(3).

410 43. Lu X, Wang L, Sakthivel SK, Whitaker B, Murray J, Kamili S, et al. US CDC real-time reverse 411 transcription PCR panel for detection of severe acute respiratory syndrome coronavirus 2 . Emerging 412 infectious diseases. 2020;26(8):1654.

413 44. Oulas A, Zanti M, Tomazou M, Zachariou M, Minadakis G, Bourdakou MM, et al. Generalized 414 linear models provide a measure of virulence for specific mutations in SARS-CoV-2 strains. bioRxiv. 2020.

415 45. Geoghegan JL, Holmes EC. The phylogenomics of evolving virus virulence. Nature Reviews 416 Genetics. 2018;19(12):756-69.

417 46. Grasselli G, Pesenti A, Cecconi M. Critical care utilization for the COVID-19 outbreak in

418 Lombardy, Italy: early experience and forecast during an emergency response. Jama.

419 2020;323(16):1545-6.

420 47. White DB, Lo B. A framework for rationing ventilators and critical care beds during the COVID-19 421 pandemic. Jama. 2020;323(18):1773-4.

422 48. Chin V, Samia NI, Marchant R, Rosen O, loannidis JP, Tanner MA, et al. A case study in model 423 failure? COVID-19 daily deaths and ICU bed utilisation predictions in New York State. European Journal 424 of Epidemiology. 2020;35(8):733-42. 
medRxiv preprint doi: https://doi.org/10.1101/2020.12.01.20242149; this version posted December 3, 2020. The copyright holder for this preprint (which was not certified by peer review) is the author/funder, who has granted medRxiv a license to display the preprint in perpetuity.

This article is a US Government work. It is not subject to copyright under 17 USC 105 and is also made available for use under a CCO license.

\section{Figures}

\section{Figure 1A:}

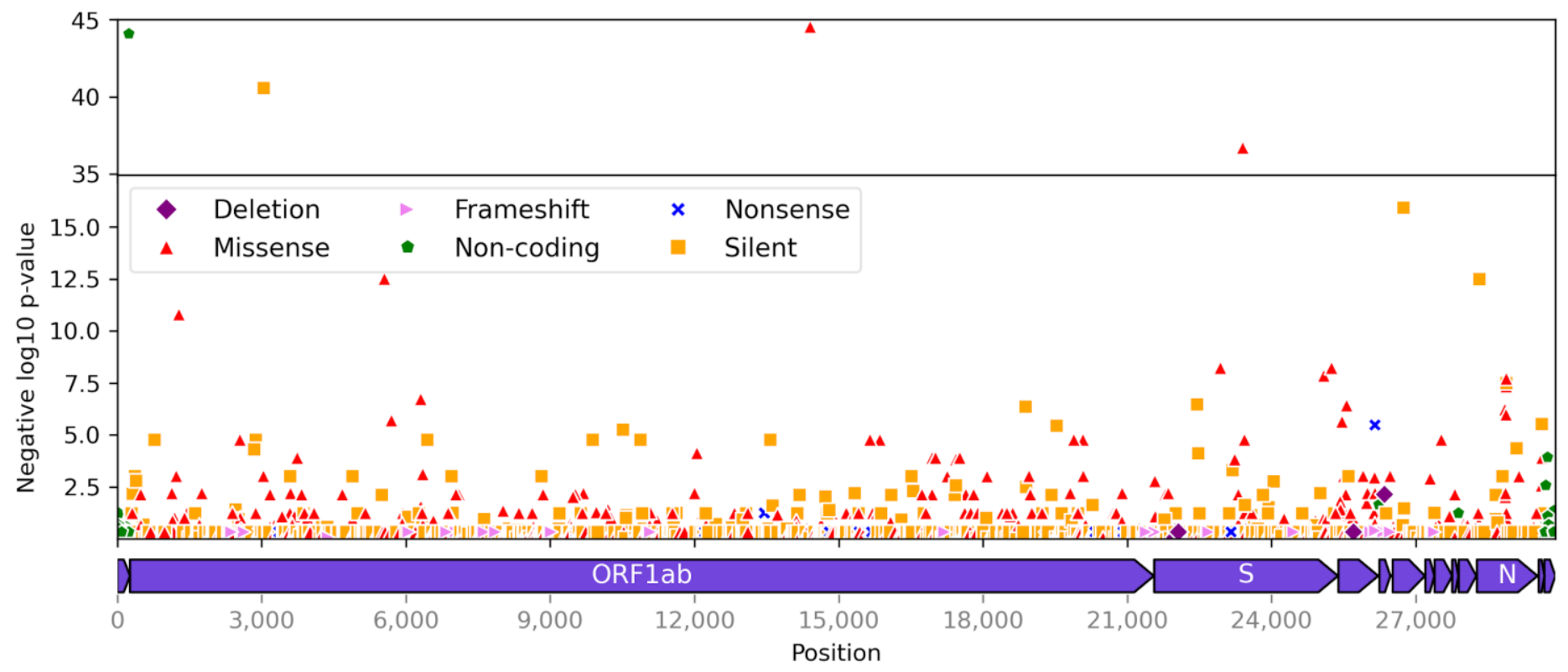

429 Figure 1B:

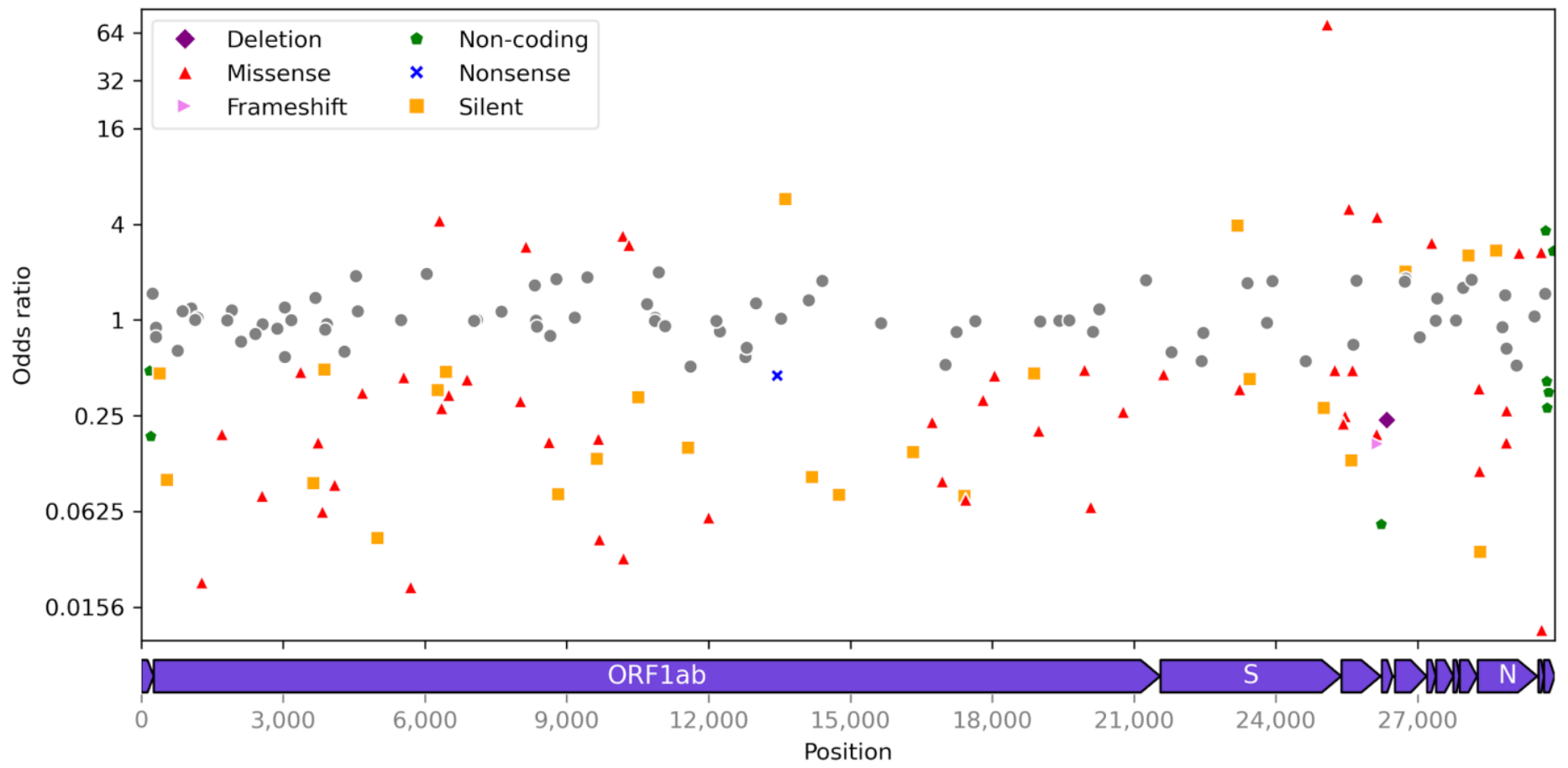


medRxiv preprint doi: https://doi.org/10.1101/2020.12.01.20242149; this version posted December 3, 2020. The copyright holder for this preprint (which was not certified by peer review) is the author/funder, who has granted medRxiv a license to display the preprint in perpetuity.

This article is a US Government work. It is not subject to copyright under 17 USC 105 and is also made available for use under a CCO license.

432

Figure 1C:

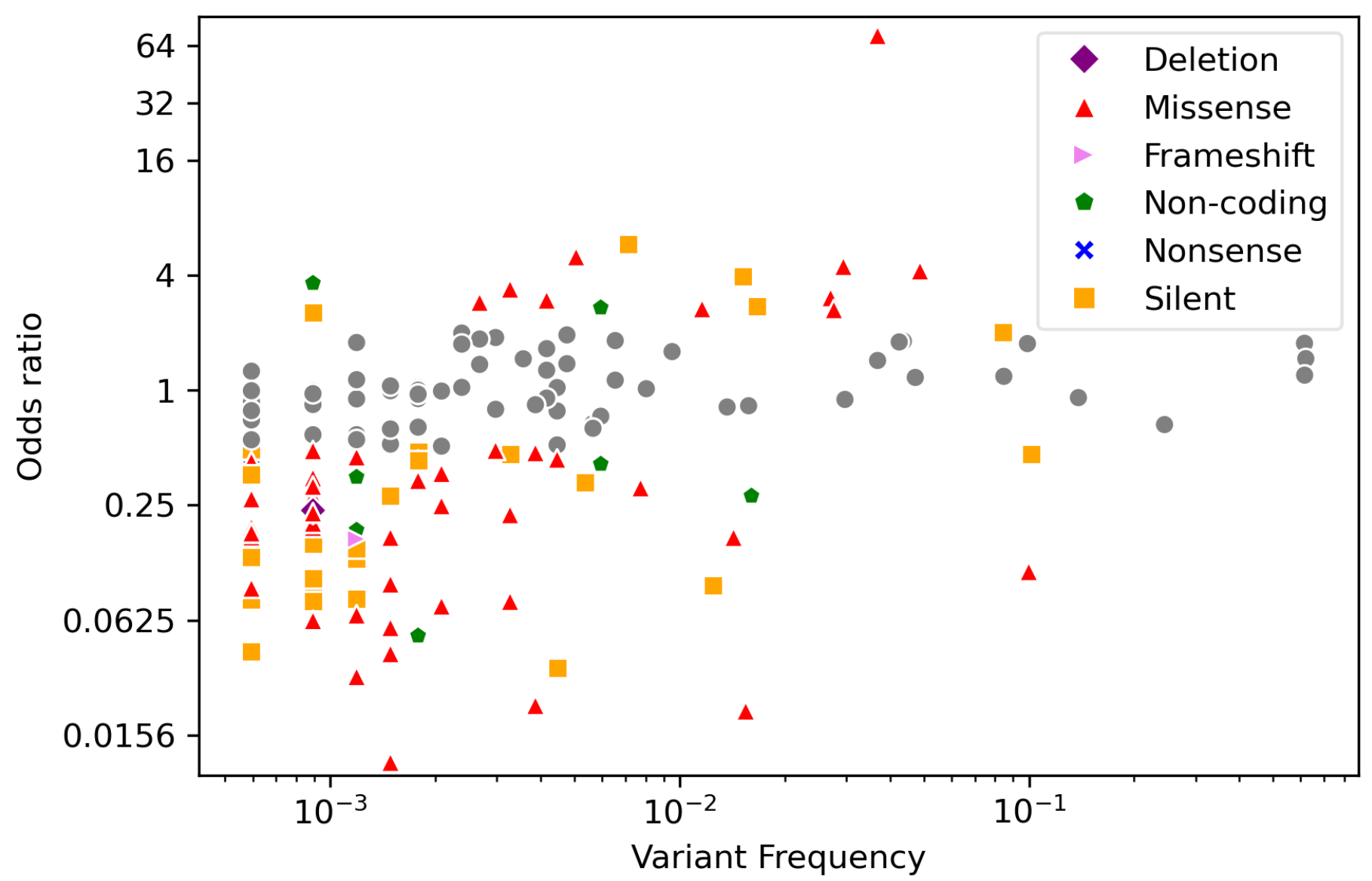




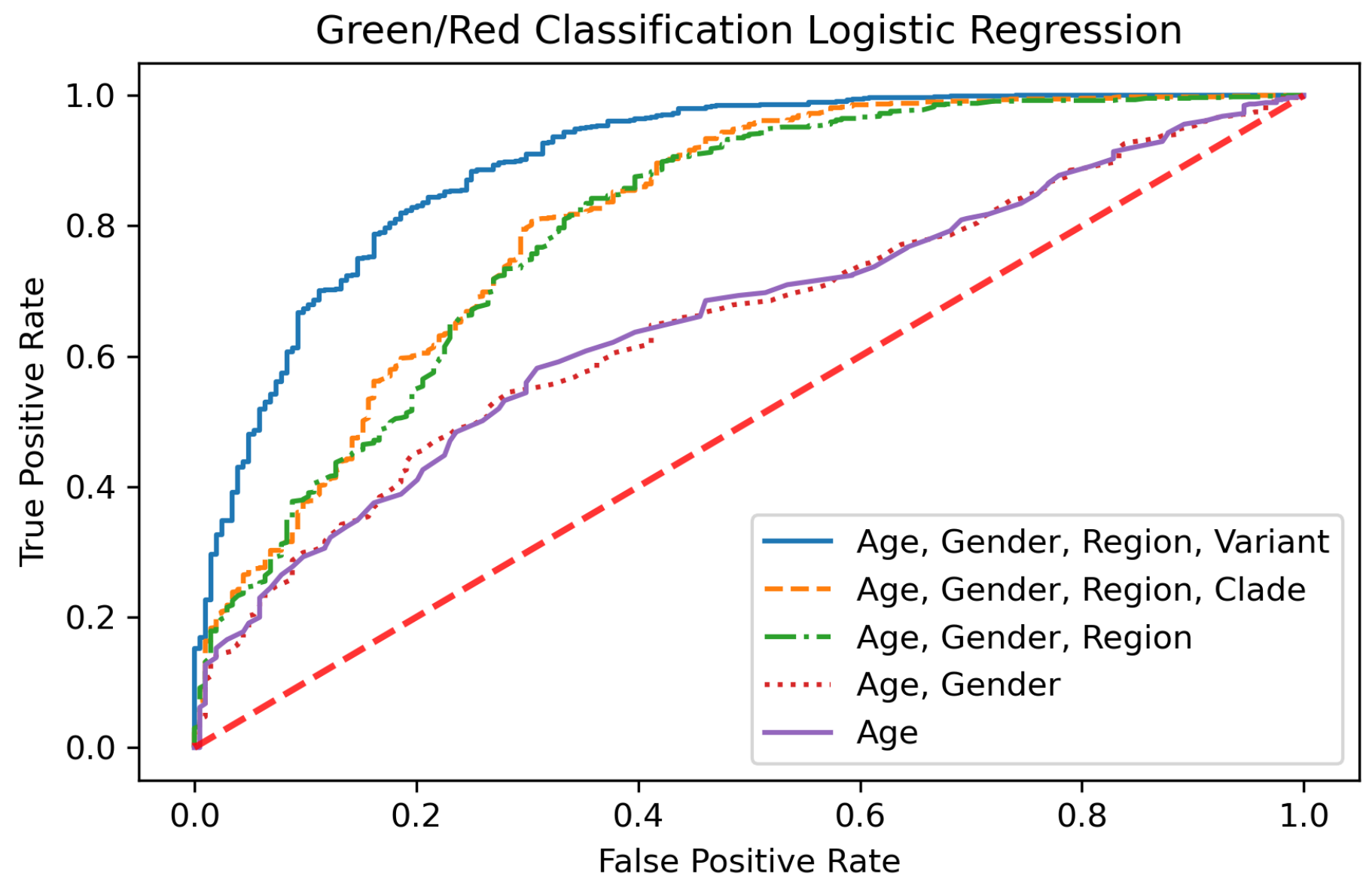


medRxiv preprint doi: https://doi.org/10.1101/2020.12.01.20242149; this version posted December 3, 2020. The copyright holder for this preprint (which was not certified by peer review) is the author/funder, who has granted medRxiv a license to display the preprint in perpetuity.

This article is a US Government work. It is not subject to copyright under 17 USC 105 and is also made available for use under a CCO license.

\section{$438 \quad$ Figure Legends}

439 Figure 1: Overview of SARS-CoV-2 variants selected from GISAID data ( $\mathrm{n}=$ 440 1595168).

441 A) Negative log10 p-values of variant association (chi-square test) with "Severe" 442 outcome group (hospitalized, deceased, etc.) plotted against position of variants $443(n=4484)$ in the SARS-CoV-2 genome.

444 B) Odds ratios (log2 scale) of "Severe" versus "Mild" (outpatient, asymptomatic, 445 etc.) outcome groups plotted against the positions of variants with odds ratios 446 not equal to one $(n=169)$ in the SARS-CoV-2 genome.

447 C) Odds ratios (log2 scale) of "Severe" versus "Mild" outcome groups plotted 448 against $\log 10$ frequency of variants $(n=169)$ in the patient subpopulation $(n=$ 4493363 ) without missing variables.

450 Points are labeled by mutation type (red: missense, green: non-coding, orange: 451 silent, yellow: nonsense, purple: deletion).

452

453 Figure 2: Comparison of nested logistic regression models.

454 Models are labeled based on the predictor variables (purple solid line: age; red 455 dotted line: [age, gender], green dash-dotted line: [age, gender, region], orange 456 dashed line: [age, gender, region, clade], blue solid line: [age, gender, region, 457 variant]) used to predict whether SARS-CoV-2 patients $(n=3363)$ belong to 458 "Severe" (hospitalized, deceased) or "Mild" (outpatient, asymptomatic, etc.) 459 outcome groups. 
medRxiv preprint doi: https://doi.org/10.1101/2020.12.01.20242149; this version posted December 3, 2020. The copyright holder for this preprint (which was not certified by peer review) is the author/funder, who has granted medRxiv a license to display the preprint in perpetuity. This article is a US Government work. It is not subject to copyright under 17 USC 105 and is also made available

\section{Supplemental Figures}

463

464

Figure S1:

告

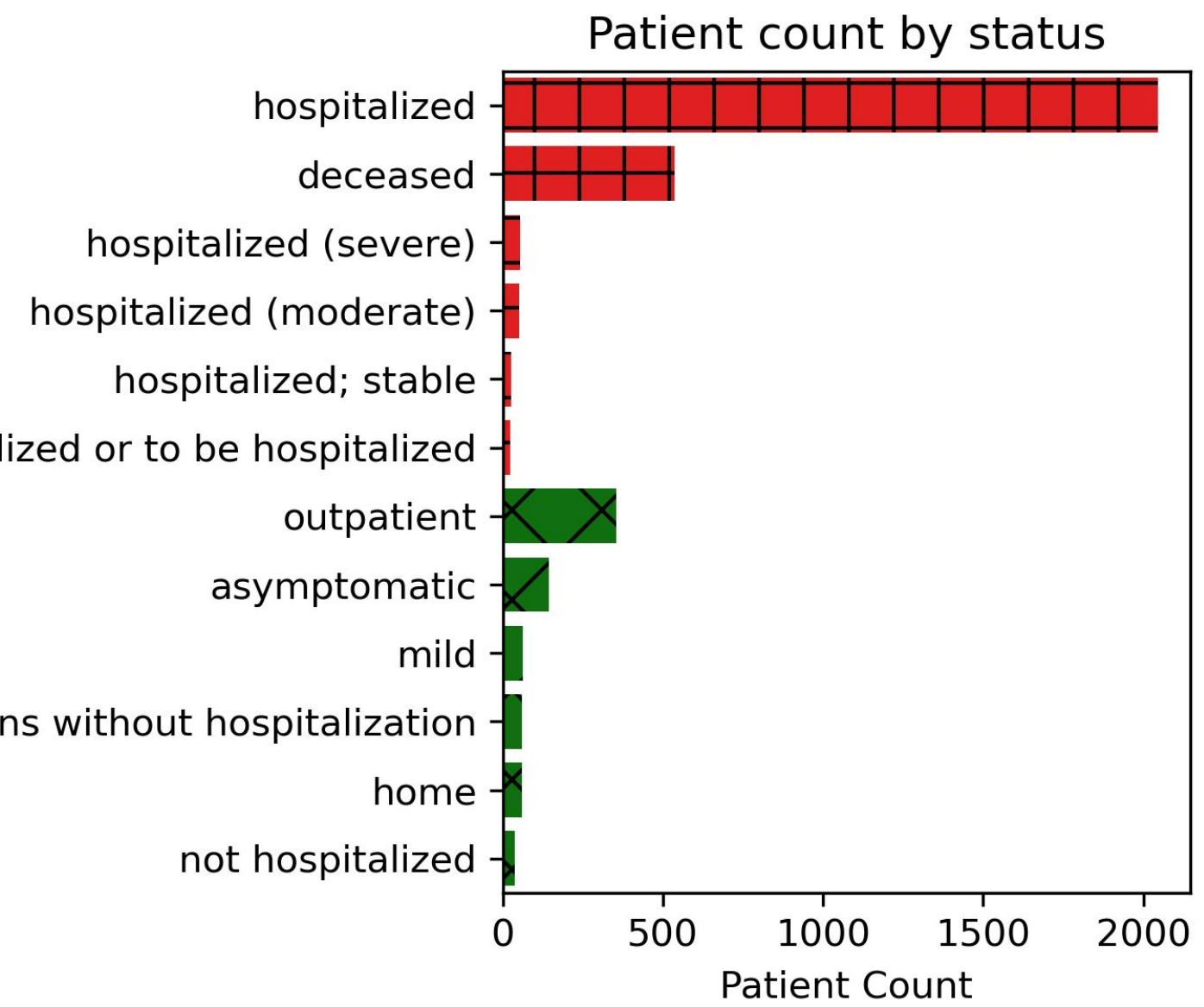


medRxiv preprint doi: https://doi.org/10.1101/2020.12.01.20242149; this version posted December 3, 2020. The copyright holder for this preprint (which was not certified by peer review) is the author/funder, who has granted medRxiv a license to display the preprint in perpetuity.

This article is a US Government work. It is not subject to copyright under 17 USC 105 and is also made available for use under a CCO license.

467 Figure S2A:

Africa

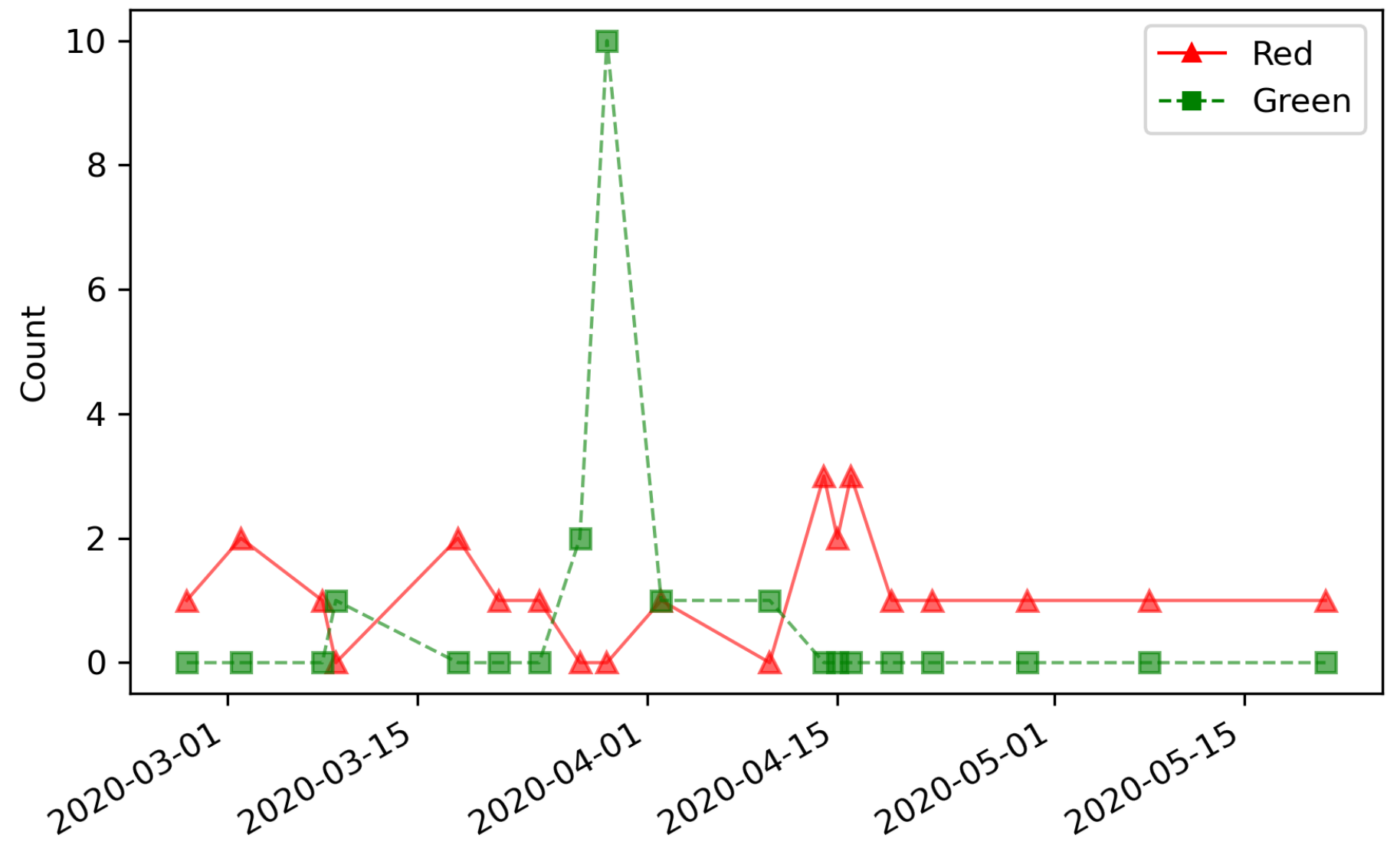


medRxiv preprint doi: https://doi.org/10.1101/2020.12.01.20242149; this version posted December 3, 2020. The copyright holder for this preprint (which was not certified by peer review) is the author/funder, who has granted medRxiv a license to display the preprint in perpetuity.

This article is a US Government work. It is not subject to copyright under 17 USC 105 and is also made available for use under a CCO license.

Figure S2B:

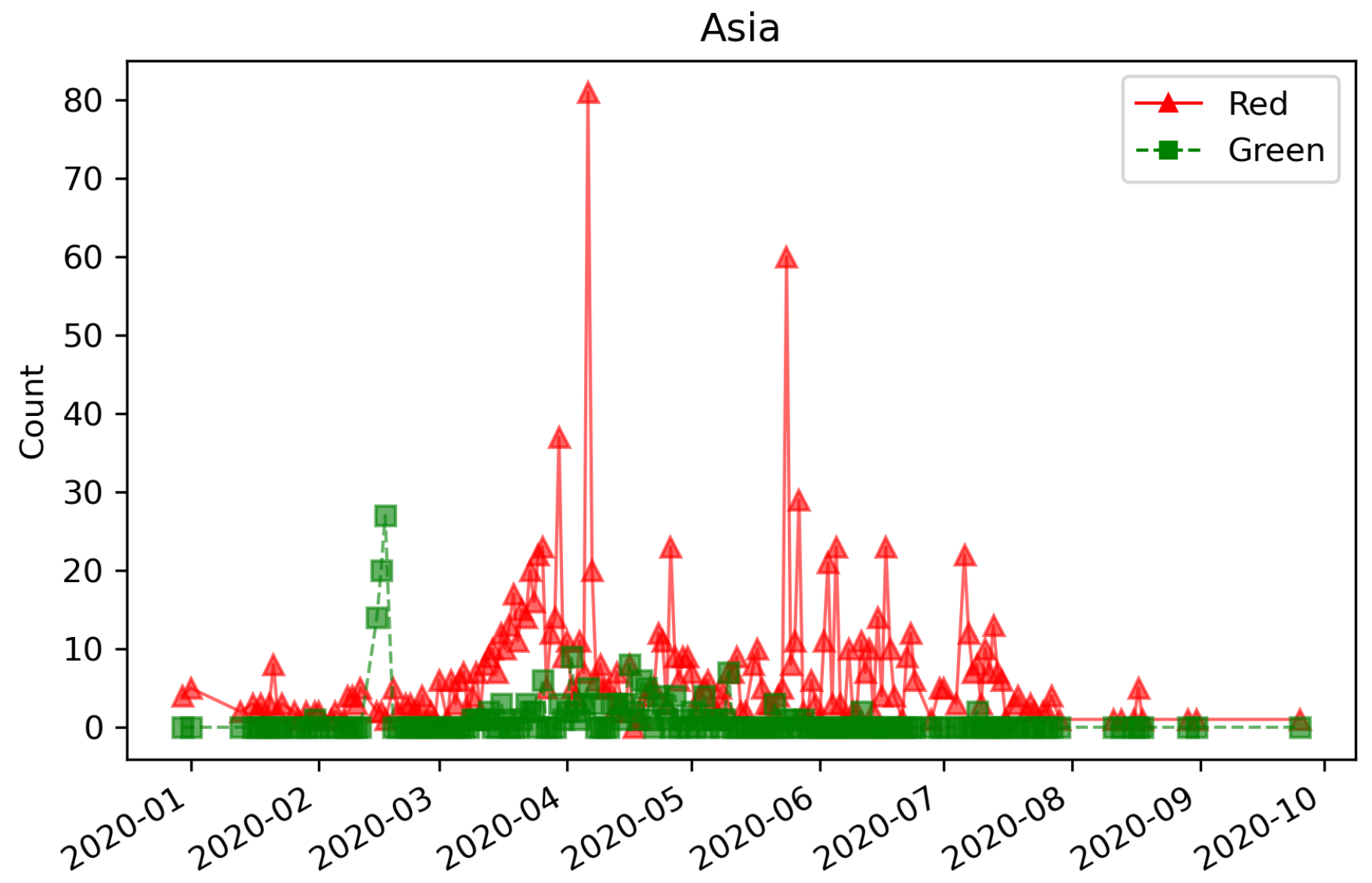


medRxiv preprint doi: https://doi.org/10.1101/2020.12.01.20242149; this version posted December 3, 2020. The copyright holder for this preprint (which was not certified by peer review) is the author/funder, who has granted medRxiv a license to display the preprint in perpetuity.

This article is a US Government work. It is not subject to copyright under 17 USC 105 and is also made available for use under a CCO license.

472 Figure S2C:

\section{Europe}

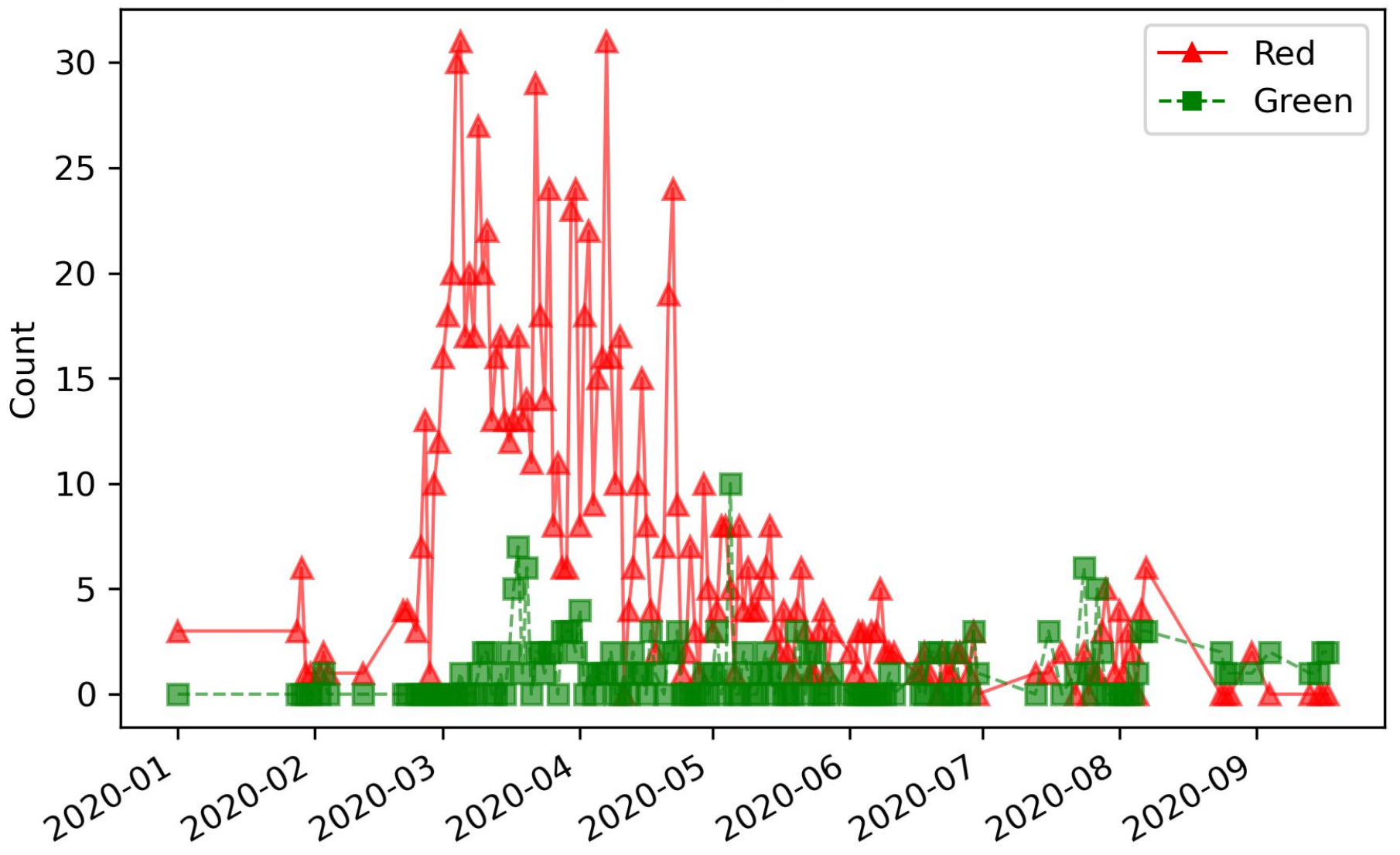

474 
medRxiv preprint doi: https://doi.org/10.1101/2020.12.01.20242149; this version posted December 3, 2020. The copyright holder for this preprint (which was not certified by peer review) is the author/funder, who has granted medRxiv a license to display the preprint in perpetuity.

This article is a US Government work. It is not subject to copyright under 17 USC 105 and is also made available for use under a CCO license.

\section{Figure S2D:}

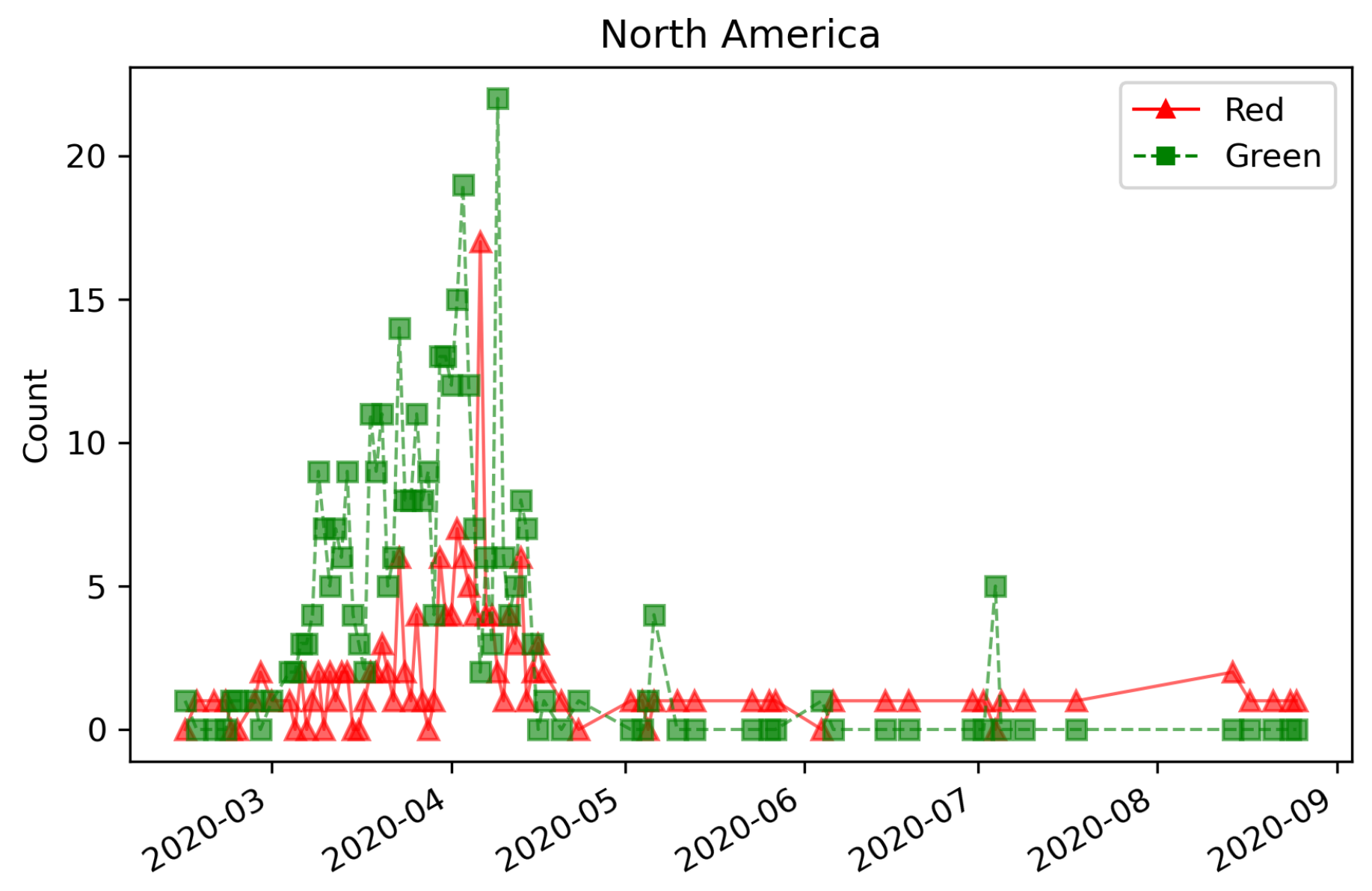

Figure S2E: 
medRxiv preprint doi: https://doi.org/10.1101/2020.12.01.20242149; this version posted December 3, 2020. The copyright holder for this preprint (which was not certified by peer review) is the author/funder, who has granted medRxiv a license to display the preprint in perpetuity.

This article is a US Government work. It is not subject to copyright under 17 USC 105 and is also made available for use under a CCO license.

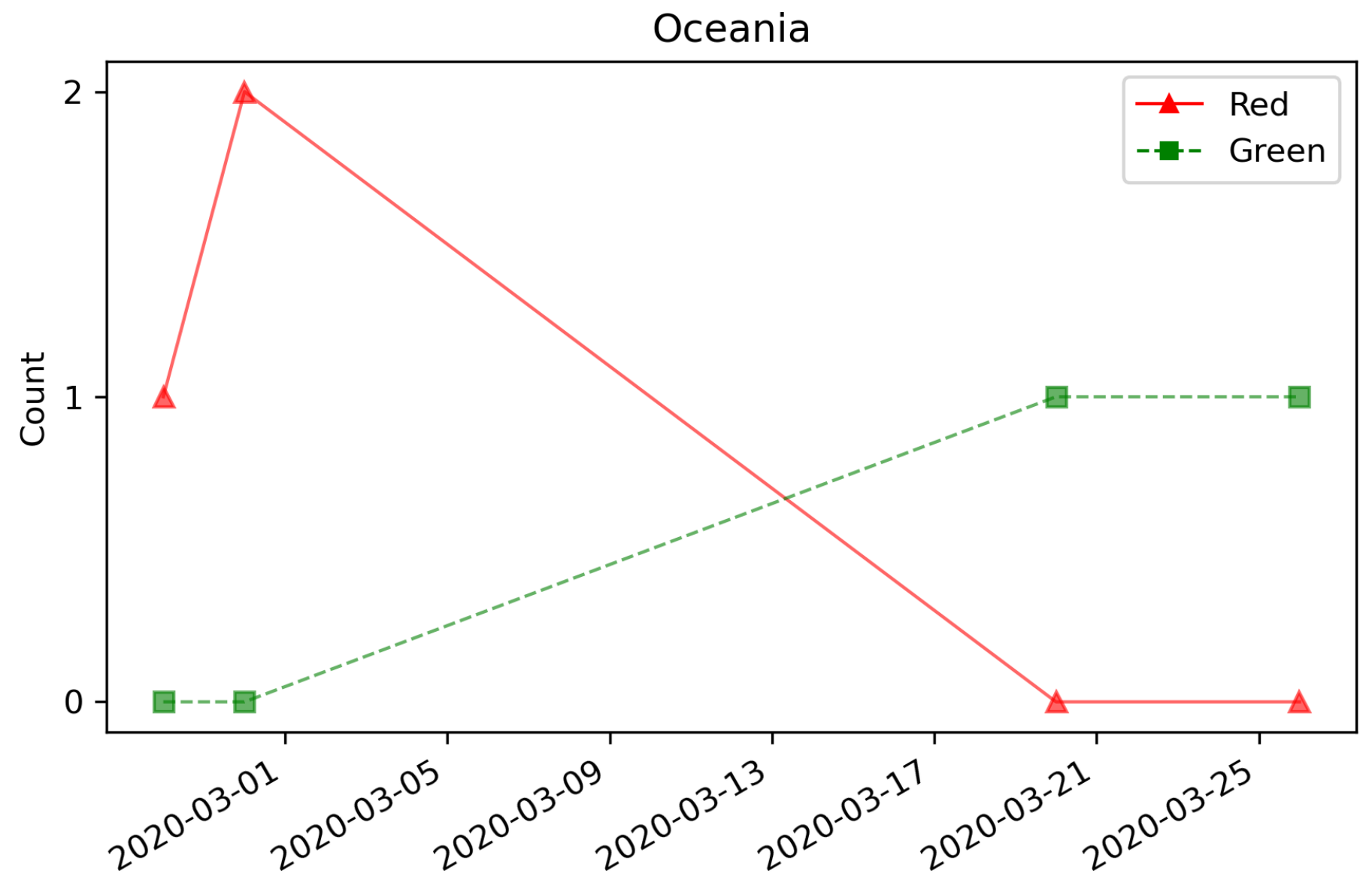

479

480

Figure S2F: 
medRxiv preprint doi: https://doi.org/10.1101/2020.12.01.20242149; this version posted December 3, 2020. The copyright holder for this preprint (which was not certified by peer review) is the author/funder, who has granted medRxiv a license to display the preprint in perpetuity.

This article is a US Government work. It is not subject to copyright under 17 USC 105 and is also made available for use under a CCO license.

South America

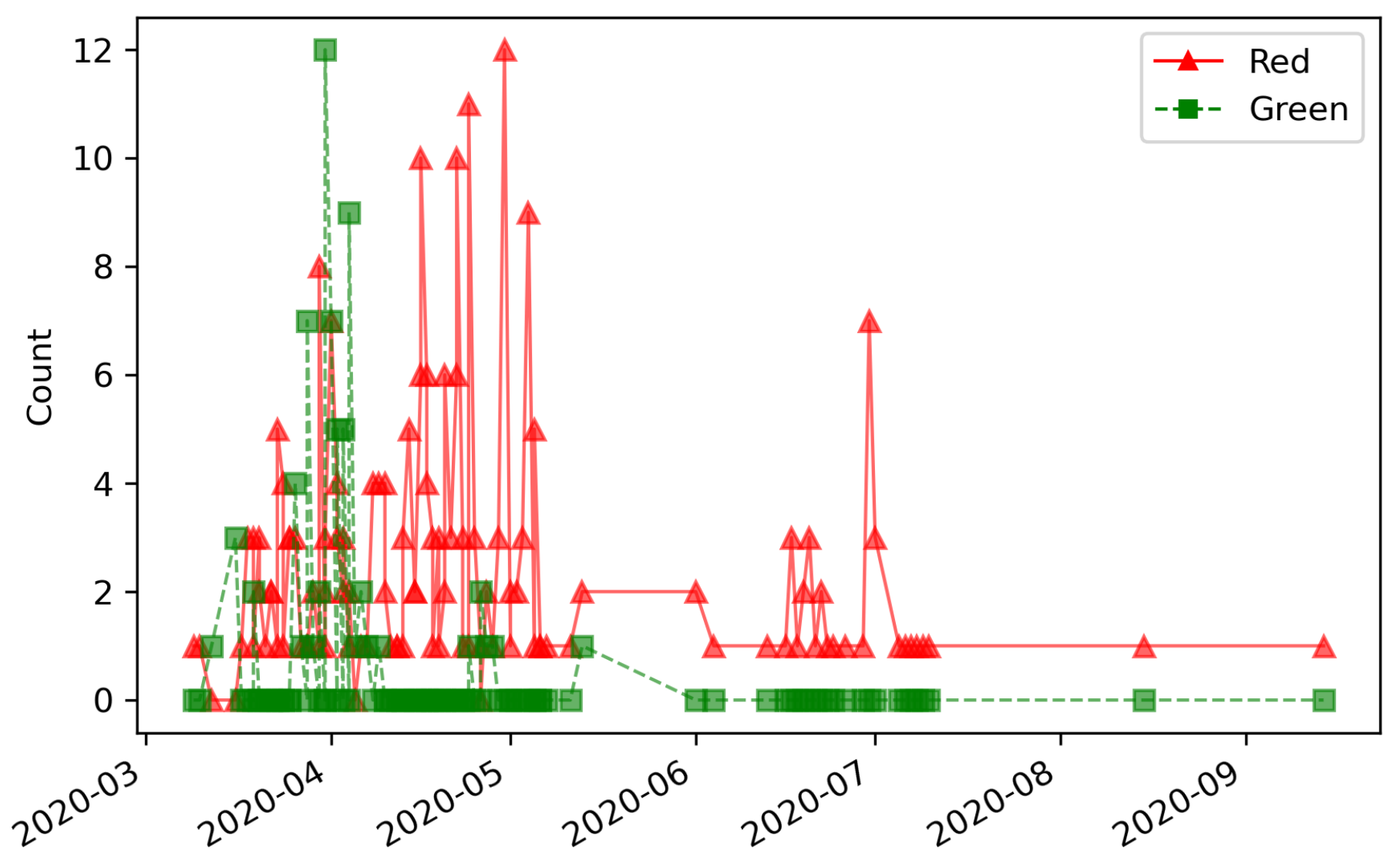


medRxiv preprint doi: https://doi.org/10.1101/2020.12.01.20242149; this version posted December 3, 2020. The copyright holder for this preprint (which was not certified by peer review) is the author/funder, who has granted medRxiv a license to display the preprint in perpetuity.

This article is a US Government work. It is not subject to copyright under 17 USC 105 and is also made available for use under a CCO license.

483

Figure S3A:

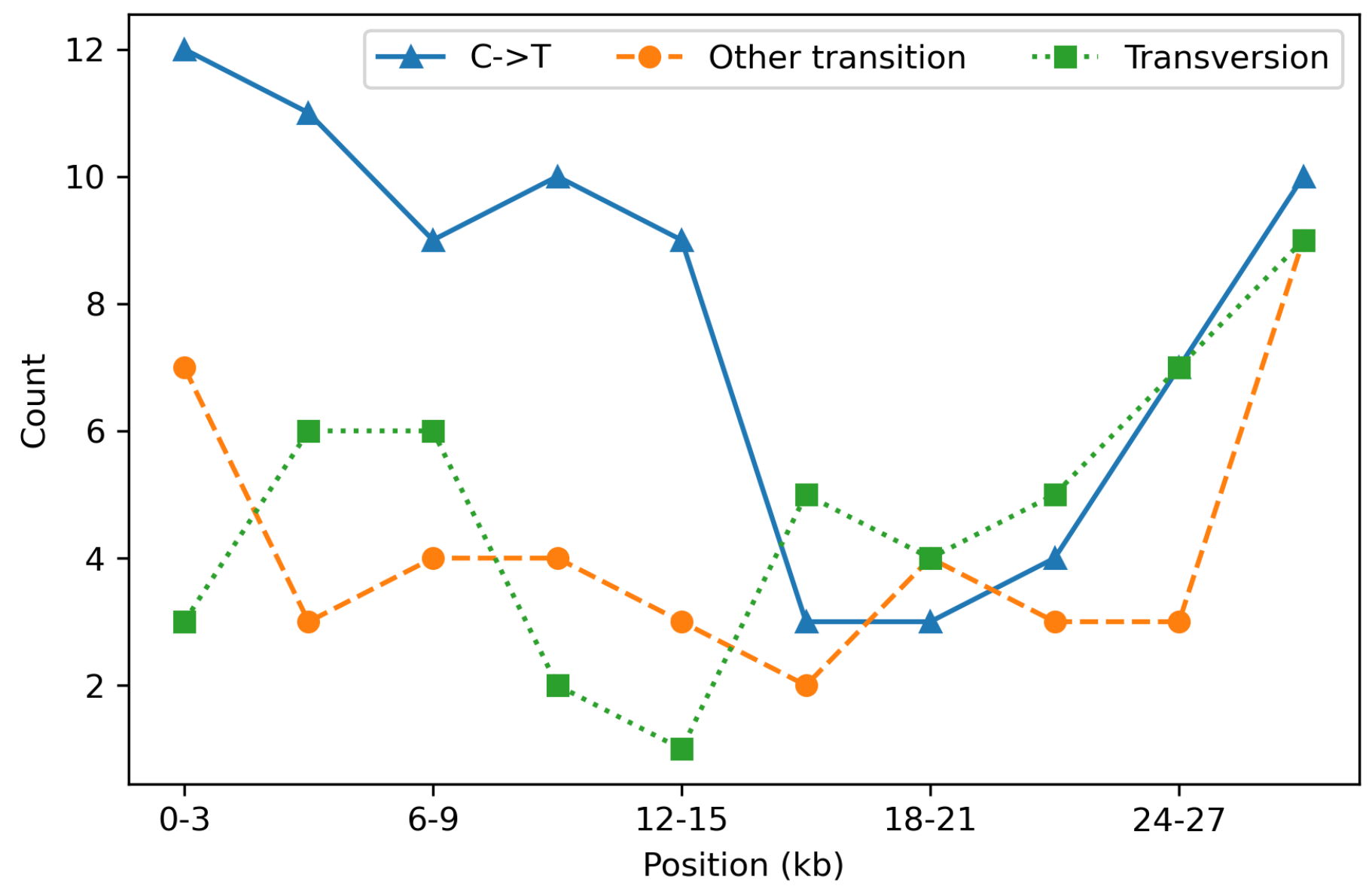


medRxiv preprint doi: https://doi.org/10.1101/2020.12.01.20242149; this version posted December 3, 2020. The copyright holder for this preprint (which was not certified by peer review) is the author/funder, who has granted medRxiv a license to display the preprint in perpetuity. This article is a US Government work. It is not subject to copyright under 17 USC 105 and is also made available for use under a CCO license.

Figure S3B:

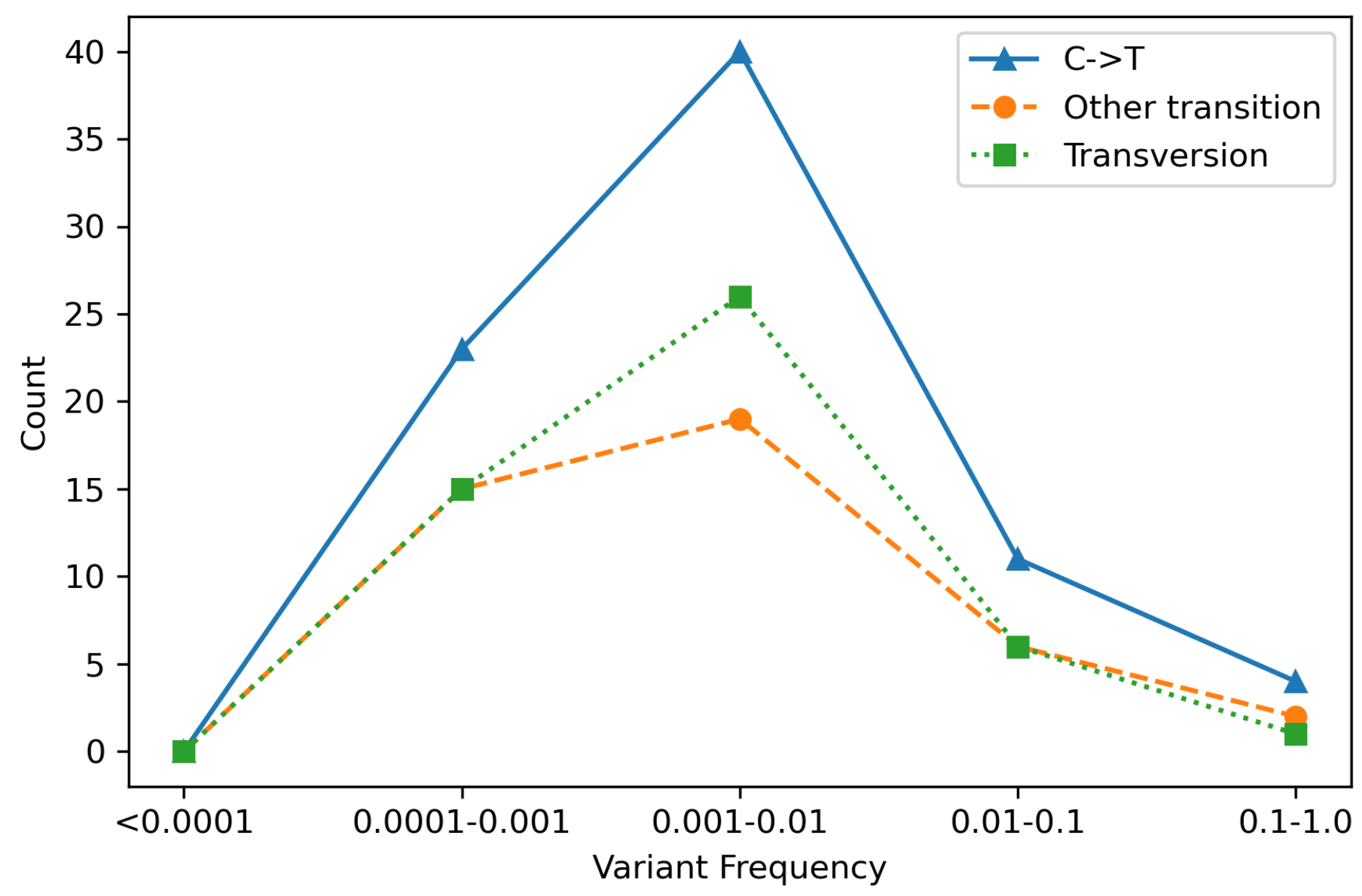


medRxiv preprint doi: https://doi.org/10.1101/2020.12.01.20242149; this version posted December 3, 2020. The copyright holder for this preprint (which was not certified by peer review) is the author/funder, who has granted medRxiv a license to display the preprint in perpetuity. This article is a US Government work. It is not subject to copyright under 17 USC 105 and is also made available for use under a CCO license.

Figure S3C:

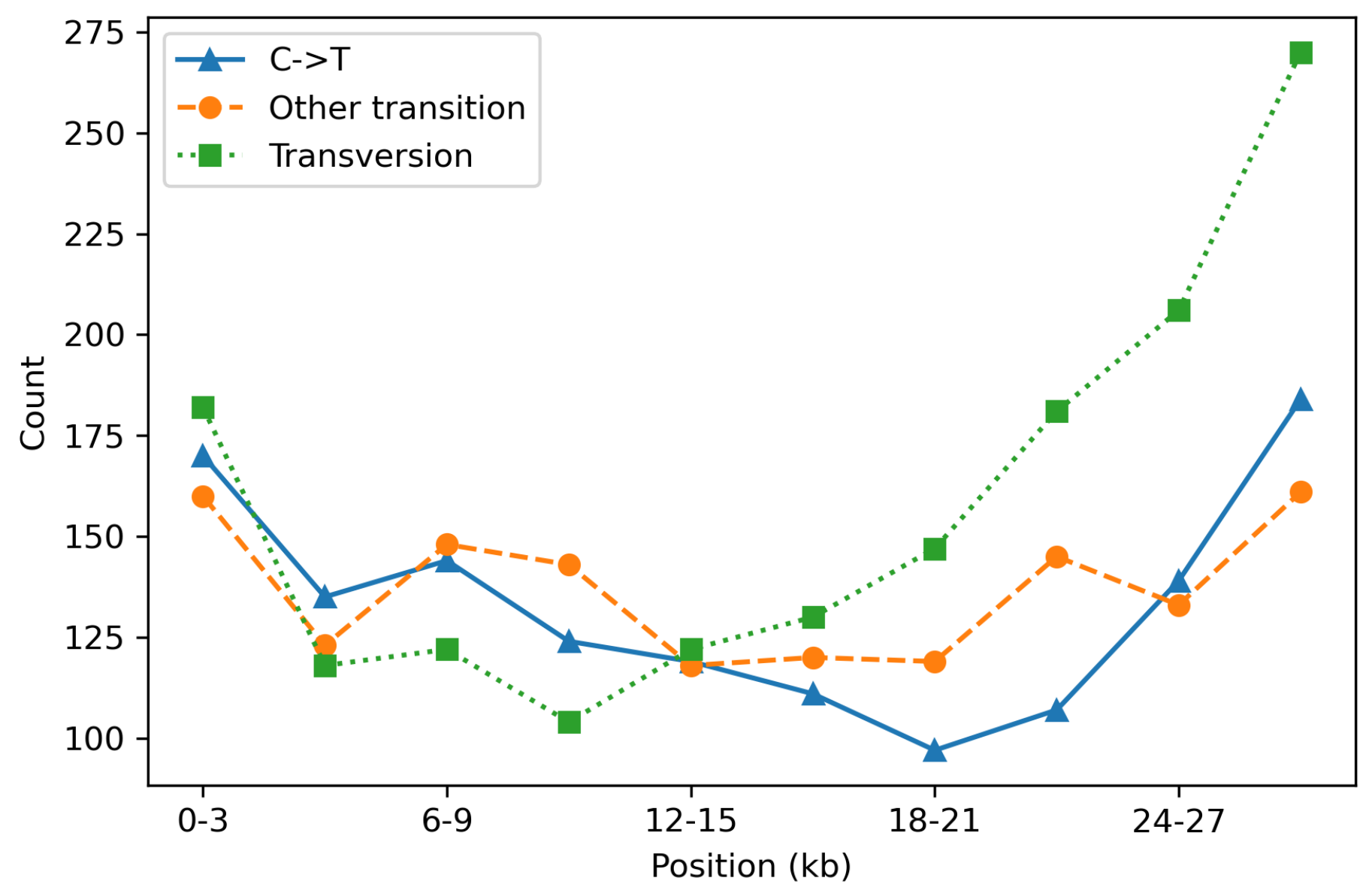

491 
medRxiv preprint doi: https://doi.org/10.1101/2020.12.01.20242149; this version posted December 3, 2020. The copyright holder for this preprint (which was not certified by peer review) is the author/funder, who has granted medRxiv a license to display the preprint in perpetuity. This article is a US Government work. It is not subject to copyright under 17 USC 105 and is also made available for use under a CCO license.

Figure S3D:

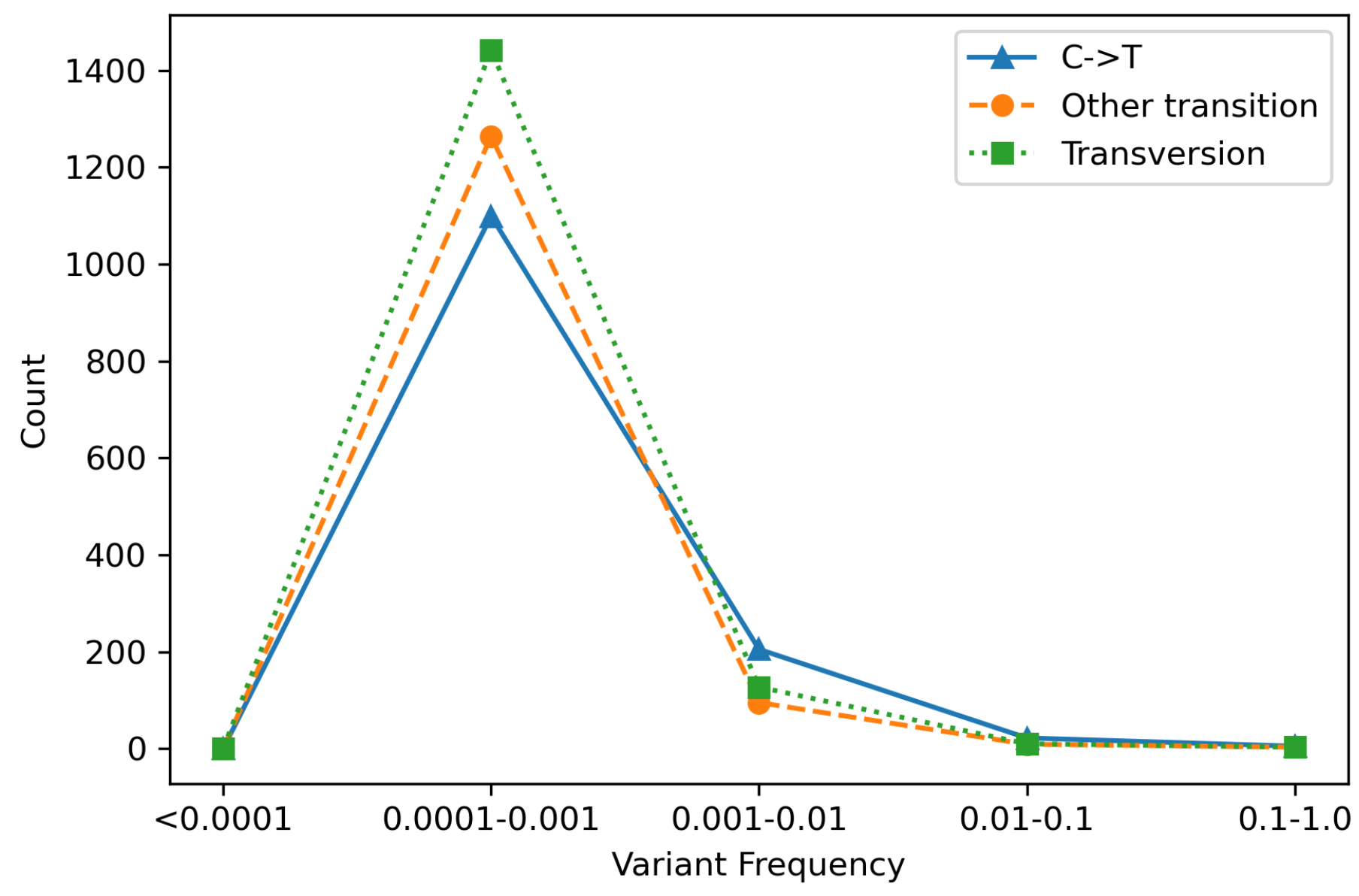


medRxiv preprint doi: https://doi.org/10.1101/2020.12.01.20242149; this version posted December 3, 2020. The copyright holder for this preprint (which was not certified by peer review) is the author/funder, who has granted medRxiv a license to display the preprint in perpetuity.

This article is a US Government work. It is not subject to copyright under 17 USC 105 and is also made available for use under a CCO license.

495

496

497

498

499

500

501

502

503

504

505

506

507

508

509

510

511

512

513

514

515

516

517

518

519

520

\section{Supplemental Figure Legends}

Figure S1: SARS-CoV-2 patient $(n=3611)$ composition of "Severe" and "Mild" outcome groups.

Bars are labeled by group membership (red vertical-horizontal hatch: [severe, symptomatic, deceased], green diagonal hatch: [live, released, mild, recovered, asymptomatic]).

Figure S2: "Severe" and "Mild" outcome counts ( $n=3611)$ over time for all GISAID regions.
A) Africa $(n=37)$

B) Asia $(n=1454)$

C) Europe $(n=1265)$

D) North America $(n=499)$
E) Oceania $(n=5)$

F) South America $(n=351)$

Curves are labeled by outcome group (red solid line: "Severe" outcome, green dotted line: "Mild" outcome).

Dates (x-axis) are shown in YYYY-MM or YYYY-MM-DD format.

Figure S3: Number of C to $\mathrm{T}$ transitions (C->T) compared to other mutation types.

A) The counts of variants with odds ratios not equal to one $(n=170)$ plotted against log10 variant frequency half-open intervals, e.g. [0.01, 0.1).

B) The counts of variants with odds ratios not equal to one $(n=170)$ plotted 17 against half-open intervals of 3 kilobases (kb), e.g. $[0,3000)$ in the SARS-CoV-2 18 genome.

C) The counts of variants used for logistic regression modeling ( $n=4484)$ plotted 
medRxiv preprint doi: https://doi.org/10.1101/2020.12.01.20242149; this version posted December 3, 2020. The copyright holder for this preprint (which was not certified by peer review) is the author/funder, who has granted medRxiv a license to display the preprint in perpetuity.

This article is a US Government work. It is not subject to copyright under 17 USC 105 and is also made available for use under a CCO license.

521 D) The counts of variants used for logistic regression modeling $(n=4484)$ plotted

522 against half-open intervals of 3 kilobases (kb), e.g. $[0,3000)$ in the SARS-CoV-2

523 genome.

524 Curves are labeled based on mutation type (blue solid line: $\mathrm{C}->\mathrm{T}$ transition, orange dashed line:

525 other transition [C->T, T->C, A->G, G->A], green dotted line: transversion [C->A, A->C, T->G, G-

$526>T, C->G, G->C, A->T, T->A])$. 